\title{
STRATEGI PENGEMBANGAN DAYA TARIK WISATA ALAM SANGHYANG KENIT DESA RAJAMANDALA KULON BANDUNG BARAT
}

\author{
Emron Edison ${ }^{1}$ \\ STIEPAR YAPARI BANDUNG \\ emron.bdg@gmail.com \\ Merdiana Hasanah Kurnia ${ }^{2}$ \\ Alumni STIEPAR YAPARI, Bandung \\ merdianahk@gmail.com \\ Septy Indrianty ${ }^{3}$ \\ STIEPAR YAPARI BANDUNG \\ Septy_indrianty@yahoo.com
}

\begin{abstract}
The research was conducted in Rajamandala Kulon Village, west bandung Regency. It employed a qualitative research method by using SWOT Matrix. The source of interviewes were key informants from the Tourism Awareness Group (Pokdarwis) and the West Bandung Regency Tourism office. The results showed that Sanghyang kenit tourist destination has natural tourist attractions namely uniqueness, authenticity, scarcity and also it can foster enthusiasm and value for tourists. In other words, it qualifies as a tourist attraction. However, there are still several supporting factors that still need to be developed, both by the manager and the west Bandung regency tourism office. The development stage needs to be carried out based on the short, medium, and long term strategic plans.
\end{abstract}

Keywords: Development Strategy, SWOT Matrix, and Sanghyang Kenit

\begin{abstract}
ABSTRAK
Penelitian ini dilakukan di Desa Rajamandala Kulon Kabupaten Bandung Barat, dengan metode penelitian kualitatif, menggunakan Matriks SWOT. Sumber wawancara menggunakan informan kunci (key informant) dari Kelompok Sadar Wisata (Pokdarwis) dan Dinas Pariwisata Kabupaten Bandung Barat. Hasil Penelitian menunjukkan bahwa, destinasi wisata Sanghyang Kenit memiliki daya tarik wisata alam berupa; keunikan, keaslian, kelangkaan, dapat menumbuhkan semangat dan nilai bagi wisatawan, dengan kata lain sudah memenuhi syarat sebagai daya tarik wisata. Tapi masih ada beberapa faktor pendukung yang masih perlu dikembangkan, baik oleh pengelola maupun oleh pihak Dinas Pariwisata Kabupaten Bandung Barat. Tahapan pengembangan perlu dilakukan berdasarkan rencana strategis (renstra) jangka pendek, jangka menengah dan jangka panjang.
\end{abstract}

Kata Kunci: Strategi Pengembangan, Matriks SWOT, Sanghyang Kenit. 


\section{PENDAHULUAN}

Pariwisata Indonesia merupakan salah satu pendorong pembangunan nasional dan menjadi perhatian serius pemerintah pusat. Bahkan, "pariwisata merupakan industri yang sangat menjanjikan dan banyak menyerap tenaga kerja. Disisi lain, pariwisata juga memiliki dampak signifikan terhadap sektor industri-industri lainnya..." (Edison \& Wulandari, 2019). Oleh karena itu, tidaklah berlebihan jika pemerintah menetapkan beberapa rencana strategis, di antaranya membangun desa wisata dan super prioritas pada lima destinasi di Borobudur, Danau Toba, Mandalika, Labuan Bajo, dan Likupang (Edison, 2020). Namun, bukan berarti pemerintah daerah tidak perlu memperhatikan potensi daya tarik wisata di masing-masing daerahnya.

Salah satu tempat wisata yang perlu dikembangkan di Jawa Barat ada di Desa Rajamandala Kulon. Desa ini memiliki sejumlah keindahan alam yang belum banyak diketahui oleh masyarakat luas, salah satunya adalah destinasi wisata Sanghyang Kenit. Sanghyang Kenit adalah sungai yang dikelilingi oleh bebatuan gamping yang besar sehingga membentuk keindahan dan keunikan tersendiri. Di tempat ini di penuhi dengan berbagai macam bebatuan dan membentuk kolam air yang mengalir. Saat air sedang surut, biasanya digunakan oleh wisatawan untuk berenang atau sekedar bermain air. Saat air sedang deras, sungai ini biasanya digunakan untuk wisata minat khusus: arung jeram. Selain itu, di tempat wisata ini ada goa yang di dalamnya terdapat batuan stalaktit dan stalakmit yang masih utuh dan aktif.

Dari keindahan alam yang ada di Sanghyang Kenit ini, ada beberapa aspek yang belum terpenuhi terutama pada aspek sarana dan prasarana seperti yang terlihat dalam tabel berikut ini:

Tabel 1.1

\section{Data Identifikasi Masalah}

\begin{tabular}{|c|l|l|}
\hline No. & \multicolumn{1}{|c|}{ Fasilitas } & \multicolumn{1}{c|}{ Keterangan } \\
\hline 1. & Toilet & Belum ada \\
\hline 2. & Kamar ganti & Belum ada \\
\hline 3. & Tempat ibadah & Belum ada \\
\hline 4. & Petunjuk arah & Belum lengkap \\
\hline 5. & Rambu-rambu keselamatan & Belum lengkap \\
\hline 6. & Jalan menuju lokasi & Belum ditata dengan baik \\
\hline
\end{tabular}

Sumber: Hasil pengamatan langsung peneliti.

Selain aspek sarana dan prasarana, kawasan ini belum dikelola secara optimal, padahal kekuatan dan keindahan alam yang ada memiliki pesona yang luar biasa. Dari dasar identifikasi masalah ini, penulis tertarik untuk mengkaji lebih mendalam tentang desitnasi ini.

\section{Landasan Teori}

Destinasi pariwisata adalah area atau kawasan geografis yang berbeda dalam suatu atau lebih wilayah administratif yang di dalamnya terdapat unsur: daya tarik wisata, fasilitas pariwisata, aksesibilitas, masyarakat serta wisatawan yang saling terikat dan melengkapi untuk terwujudnya kegiatan kepariwisataan" (Suryadana \& Octavia, 2015). Ini menunjukkan bahwa destinasi pariwisata ada keterkaitannya dengan daya Tarik wisata. 
Daya tarik wisata adalah suatu objek ciptaan Tuhan maupun hasil karya manusia, yang menarik minat orang untuk berkunjung dan menikmati keberadaannya (Yoeti dalam Lesmana et.al., 2018). Lebih lanjut dijelaskan bahwa, "Daya tarik wisata adalah segala sesuatu yang menjadi pemicu kunjungan wisatawan, dengan destinasi atau tujuan yang berupa sarana/objek seperti benda-benda yang tersedia di alam dan hasil ciptaan manusia (Warpani dalam Khaerani et al., 2017)

Menurut Suryadana dan Oktavia (2015), suatu daerah dikatakan memiliki daya tarik wisata bila memiliki sifat: 1) Keunikan, contoh: bakar batu (di Papua) sebuah masak cara tradisional mulai dari upacara memotong hewan (babi) sampai membakar daging, sayuran dan umbi/talas yang disekam dalam lubang, ditutup batu lalu dibakar, serta keunikan cara memakan masakan tersebut; 2) Keaslian, alam dan adat yang dilakukan sehari-hari, dalam berpakaian dan kehidupan keluarga di mana seorang perempuan lebih mengutamakan menggendong babi yang dianggapnya sangat berharga daripada menggendong anaknya sendiri; 3) Kelangkaan, sulit ditemui di daerah/negara lain, dan; 4) Menumbuhkan semangat dan memberikan nilai bagi wisatawan.

\section{Strategi Pengembangan Pariwisata}

Strategi merupakan alat untuk mencapai tujuan perusahaan dalam kaitannya dengan tujuan jangka panjang, program tindak lanjut, serta prioritas alokasi sumber daya (Chandler dalam Rangkuti, 2013). Sedangkan manfaat pengembangan pariwisata dijelaskan bahwa, "pengembangan potensi pariwisata yang dimiliki setiap daerah di Indonesia sangat diperlukan dan sangat dibutuhkan. Pengembangan potensi ini menjadi sangat bermakna dalam upaya meningkatkan daya tarik bagi wisatawan" (Zebua, 2016). Bahkan, "pengembangan kepariwisataan bertujuan memberikan keuntungan baik bagi wisatawan maupun warga setempat..." (Marpaung dalam Kartika et.al. 2018). Dengan demikian dapat disimpulkan bahwa strategi pengembangan pariwisata adalah alat untuk tujuan jangka panjang dalam upaya meningkatkan daya tarik wisata, serta dapat memberikan keuntungan baik bagi wisatawan maupun bagi warga setempat.

Menurut Yoeti (dalam Edison., et.al. 2018), pada dasarnya terdapat beberapa faktor yang perlu diperhatikan dalam menentukan pengembangan pariwisata, yaitu:

1. Accessibilitas of the destination. Pada dasarnya semua prasarana yang memberikan kemudahan bagi wisatawan untuk datang berkunjung pada suatu DTW (Daerah Tujuan Wisata) tanpa itu tidak mungkin pariwisata dikembangkan sebagai suatu industri. Artinya kemudahan mencapai daerah tujuan wisata yang dimaksud melalui berbagai media transportasi, baik darat, laut maupun udara.

2. Facilities of destination. Yaitu semua bentuk fasilitas yang memberikan pelayanan bagi wisatawan untuk segala kebutuhan selama tinggal atau berkunjung ke suatu DTW (Daerah Tujuan wisata) tersebut. Hal tersebut antara lain akomodasi yang nyaman, restoran, bar, layanan informasi, pramuwisata, sikap masyarakat, setempat, keamanan, dan lain-lain.

3. Attraction of the destination. Yaitu semua objek dan atraksi yang tersedia sebagai daya tarik mengapa wisatawan mau datang berkunjung ke DTW (Daerah Tujuan Wisata). Dimana segala sesuatu baik yang berupa daya tarik wisata alam dan budaya yang menarik bagi wisatawan untuk datang ke suatu daerah tujuan wisata, hal ini antara lain meliputi keindahan alam, pantai, atraksi wisata, budaya, kebiasaan, dan cara hidup masyarakat, keunikan alam, dan budaya, atraksiatraksi seni, pertemuan ilmiah, dagang, dan sebagainya. 
Lebih lanjut, Carter dan Fabricius (dalam Sunaryo, 2013) menjelaskan ada berbagai elemen dasar yang harus diperhatikan dalam perencanaan pengembangan sebuah destinasi pariwisata, paling tidak akan mencakup aspek-aspek sebagai berikut:

1. Pengembangan Atraksi dan Daya Tarik Wisata

Atraksi merupakan daya tarik yang akan melahirkan motivasi dan keinginan bagi wisatawan untuk mengunjungi destinasi. Berbagai wujud dari atraksi wisata ini dapat berupa: arsitektur bangunan (seperti: candi, piramida, monumen, masjid, gereja, dan sebagainya), karya seni budaya (seperti: museum, seni pertunjukan, seni rupa, seni sastra, kehidupan masyarakat, dsb), dan pengalaman tertentu ataupun berbagai bentuk event pertunjukan.

2. Pengembangan Amenitas dan Akomodasi Wisata

Pada hakekatnya amenitas adalah merupakan fasilitas dasar seperti: utilitas, jalan raya, transportasi, akomodasi, pusat informasi pariwisata dan pusat perbelanjaan yang kesannya perlu disediakan untuk membuat wisatawan yang berkunjung ke destinasi merasa nyaman dan senang. Lebih luas, amenitas juga bisa berarti sebagai fasilitas pendukung demi kelancaran kegiatan kepariwisataan serta memberikan kenyamanan kepada wisatawan. Berbagai fasilitas wisata yang perlu dikembangkan dalam aspek amenitas tadi, paling tidak terdiri dari: akomodasi, rumah makan, pusat informasi wisata, pusat/toko cinderamata, pusat kesehatan, pusat layanan perbankan, sarana komunikasi, pos keamanan, biro perjalanan wisata, ketersediaan air bersih, dan listrik dan lain sebagainya.

3. Pengembangan Aksesibilitas

Yang dimaksud dengan aksesibilitas wisata dalam hal ini adalah: segenap sarana yang memberikan kemudahan kepada wisatawan untuk mencapai suatu destinasi maupun tujuan wisata terkait. Aksesibilitas tidak hanya menyangkut kemudahan transportasi bagi wisatawan untuk mencapai sebuah tempat wisata atau destinasi tertentu, akan tetapi juga waktu yang dibutuhkan, tanda penunjuk arah menuju lokasi wisata dan perangkat terkait lainnya.

4. Pengembangan Image (Citra Wisata)

Pencitraan (Image Building) sebuah destinasi merupakan bagian dari positioning, yaitu kegiatan untuk membangun citra atau image di benak pasar (wisatawan) melalui desain terpadu antara aspek: kualitas produk, komunikasi pemasaran, kebijakan harga, dan saluran pemasaran yang lain dibangun serta ekspresi yang tampak dari sebuah produk.

\section{METODOLOGI}

Metode penelitian pada dasarnya merupakan cara ilmiah untuk mendapatkan data dengan tujuan dan kegunaan tertentu (Sugiyono, 2010). Dalam penelitian ini peneliti menggunakan metode penelitian kualitatif. "Metode penelitian kualitatif sering disebut metode penelitian naturalistik karena penelitiannya dilakukan pada kondisi yang alamiah (natural setting); disebut juga sebagai metode etnographi, karena pada awalnya metode ini lebih banyak digunakan untuk penelitian bidang antropologi budaya; disebut sebagai metode kualitatif, karena data yang terkumpul dan analisisnya lebih bersifat kualitatif." (Sugiyono, 2016).

Dijelaskan lebih lanjut oleh Moleong (2011) mengatakan bahwa, "penelitian kualitatif adalah penelitian yang bermaksud untuk memahami fenomena tentang apa yang dialami oleh subjek penelitian misalnya perilaku, persepsi, motivasi, tindakan, dll., secara holisktik, dan dengan cara deskripsi dalam bentuk kata-kata dan bahasa, pada suatu konteks khusus yang alamiah dan dengan memanfaatkan berbagai metode alamiah." 
Pendekatan kualitatif yang peneliti gunakan yaitu melalui observasi dan wawancara yang terstruktur. Selanjutnya hasil observasi dan wawancara diukur dan diterjemahkan ke dalam Matriks SWOT yang meliputi faktor internal; Kekuatan (Strenghts), Kelemahan (Weaknesses), dan faktor eksternal; Peluang (Opportunities) dan Ancaman (Threats), berikutnya dilakukan strategi pencocokan.

Desain penelitian atau alur penelitian yang digunakan oleh penulis seperti terlihat dalam gambar berikut ini.

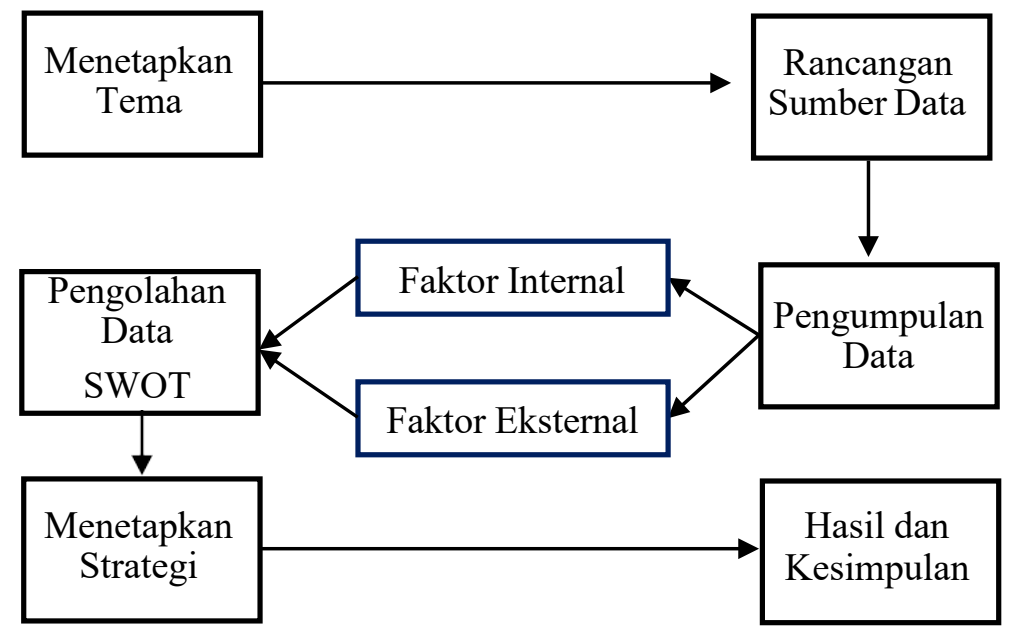

Gambar 3.1

Desain Penelitian

\section{Keterangan}

1. Menetakan tema penelitian

2. Merancang Sumber data. Agar sumber data lebih terstrukur, maka peneliti merancang instrumen sumber data (Tabel 3.1). Sedangkan sumber data didapat dari hasil observasi dan wawancara.

3. Mengumpulkan data. Dalam proses ini peneliti mengamati faktor lingkungan (internal dan eksternal) dari aspek daya tarik wisata dan pengembangan pariwisata.

4. Mengola data. Dalam proses ini, peneliti mengola data dengan menggunakan Matriks SWOT yaitu strategi pencocokan.

5. Menetapkan Strategi. Strategi yang dihasilkan didapat dari hasil Matriks SWOT.

6. Kesimpulan

Tabel 3.1

\section{Instrumen Sumber Data}

\begin{tabular}{|c|c|c|c|c|}
\hline \multicolumn{2}{|r|}{ Fokus } & Indikator & Tujuan & Sumber Data \\
\hline \multirow{2}{*}{1.} & \multirow{2}{*}{$\begin{array}{l}\text { Daya Tarik } \\
\text { Wisata }\end{array}$} & Keunikan & $\begin{array}{ll}\text { Untuk } & \text { mengetahui } \\
\text { keunikan } & \text { alam yang } \\
\text { dimiliki } & \text { Sanghyang } \\
\text { Kenit } & \end{array}$ & $\begin{array}{l}\text { Observasi dan } \\
\text { wawancara }\end{array}$ \\
\hline & & Keaslian & $\begin{array}{l}\text { Untuk mengetahui } \\
\text { keaslian alam yang } \\
\text { terdapat di } \\
\text { Sanghyang Kenit }\end{array}$ & $\begin{array}{l}\text { Observasi dan } \\
\text { wawancara }\end{array}$ \\
\hline
\end{tabular}




\begin{tabular}{|c|c|c|c|c|}
\hline & & Kelangkaan & $\begin{array}{l}\text { Untuk mengetahui } \\
\text { kelangkaan benda- } \\
\text { benda yang terdapat } \\
\text { di dalam gua } \\
\text { Sanghyang Kenit }\end{array}$ & $\begin{array}{l}\text { Observasi dan } \\
\text { wawancara }\end{array}$ \\
\hline & & $\begin{array}{l}\text { Menumbuhkan } \\
\text { semangat dan } \\
\text { memberikan } \\
\text { nilai bagi } \\
\text { wisatawan }\end{array}$ & $\begin{array}{l}\text { Untuk mengetahui } \\
\text { tingkat antusias dan } \\
\text { kepedulian } \\
\text { wisatawan untuk } \\
\text { melestarikan dan } \\
\text { tidak merusak alam }\end{array}$ & $\begin{array}{l}\text { Observasi dan } \\
\text { wawancara }\end{array}$ \\
\hline & & $\begin{array}{l}\text { Accessibilitas of } \\
\text { the destination }\end{array}$ & $\begin{array}{l}\text { Untuk mengetahui } \\
\text { kondisi aksesibilitas } \\
\text { yang ada menuju } \\
\text { Sanghyang Kenit }\end{array}$ & $\begin{array}{l}\text { Observasi dan } \\
\text { wawancara }\end{array}$ \\
\hline 2. & $\begin{array}{l}\text { Pengemba- } \\
\text { ngan } \\
\text { Pariwisata }\end{array}$ & $\begin{array}{l}\text { Facilities of the } \\
\text { destination }\end{array}$ & $\begin{array}{l}\text { Untuk mengetahui } \\
\text { tingkat fasilitas yang } \\
\text { tersedia di } \\
\text { Sanghyang Kenit }\end{array}$ & $\begin{array}{l}\text { Observasi dan } \\
\text { wawancara }\end{array}$ \\
\hline & & $\begin{array}{l}\text { Attraction of the } \\
\text { destination }\end{array}$ & $\begin{array}{l}\text { Untuk mengetahui } \\
\text { kemenarikan dan } \\
\text { ragam atraksi wisata } \\
\text { alam di Sanghyang } \\
\text { Kenit }\end{array}$ & $\begin{array}{l}\text { Observasi dan } \\
\text { wawancara }\end{array}$ \\
\hline
\end{tabular}

\section{Sumber Data}

Sumber data didapat dari lokasi penelitian baik berupa hasil observasi dan wawancara mendalam. Wawancara dilakukan dengan pengelola destinasi wisata yaitu Kelompok Sadar Wisata Sanghyang Kenit (Pokdarwis), pemerintahan (DISPARBUD Kabupaten Bandung Barat), dan ahli pariwisata, mengenai hal yang berhubungan dengan destinasi wisata alam Sanghyang Kenit.

\section{HASIL PENELITIAN DAN PEMBAHASAN}

\section{Hasil Penelitian}

Sanghyang Kenit merupakan bagian dari kawasan Sungai Citarum Purba dan termasuk dalam Balai Besar Wilayah Sungai (BBWS). Sanghyang Kenit berlokasi di Kampung Cisameng, Desa Rajamandala Kulon, Kecamatan Cipatat, Kabupaten Bandung Barat. Keberadaan Sanghyang Kenit sudah ada sejak lama, namun lokasi ini mulanya bukan menjadi destinasi wisata namun berfungsi sebagai tempat aliran air yang berasal dari PLTA Saguling mengalir ke kawasan Sanghyang Kenit. Kini, tempat ini pun dijadikan sebagai garis awal (start) kegiatan arung jeram sepanjang $7 \mathrm{~km}$ menyusuri Sungai Citarum.

Dengan dibangunnya PLTA baru, yakni PLTA Rajamandala. Aliran air dari PLTA Saguling beralih mengalir ke PLTA Rajamandala, sehingga kawasan Sanghyang Kenit menjadi surut, dengan demikian warga sekitar mulai sering mengunjungi Sanghyang Kenit, biasanya mereka datang ke Sanghyang Kenit untuk mencari ikan.

Berdasarkan informasi dari Pokdarwis, nama Sanghyang Kenit berasal dari tiga kata yaitu kata Sang, Hyang dan Kenit. Kata Sang berarti sebutan kepada sesuatu yang di Agung-kan untuk leluhur. Kata Hyang berarti sebutan untuk sebuah tempat yang digunakan para leluhur untuk bersemedi (nyepi), sedangkan kata Kenit memiliki dua versi. Versi pertama 
menyebutkan bahwa Kenit berarti arus yang memutar. Versi kedua menyebutkan bahwa kata Kenit berasal dari nama Domba Kendit yang memiliki corak sabuk melingkar di dadanya. Pada zaman dahulu, Domba Kendit tersebut dijadikan tumbal dan disembelih di area wisata sekarang.

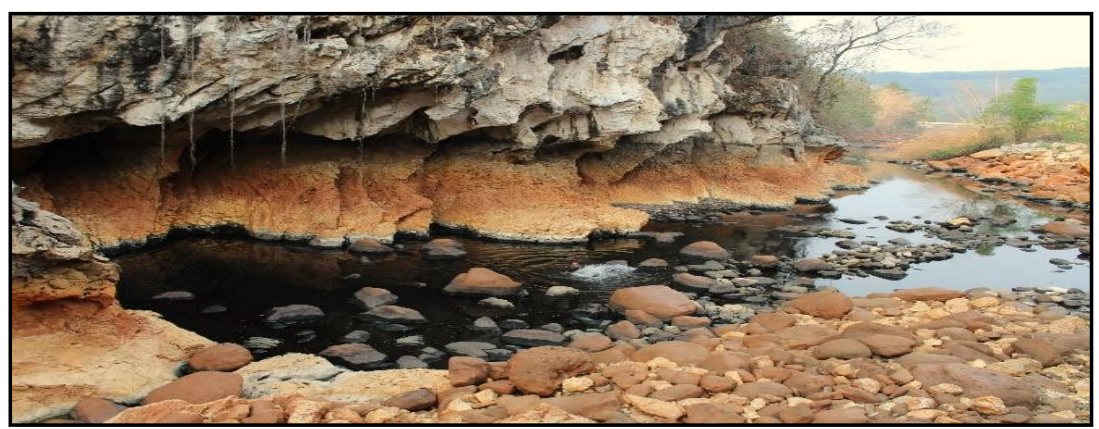

Gambar 4.1

Sanghyang Kenit (Kondisi Air Surut)

Penelitian yang dilakukan menggunakan indikator dari variabel daya tarik wisata dan pengembangan pariwisata. Indikator daya tarik wisata meliputi; keunikan, keaslian, kelangkaan, menumbuhkan semangat dan memberikan nilai bagi wisatawan. Sedangkan indikator pengembangan pariwisata meliputi; accessibilities of the destination, facilities of the destination, attraction of the destination.

Peneliti membahas hasil penelitian berdasarkan informasi yang didapatkan dari hasil observasi dan wawancara dengan pihak-pihak terkait dengan fokus penelitian di antaranya dengan Kelompok Sadar Wisata (Pokdarwis) Sanghyang Kenit, Dinas Pariwisata dan Kebudaayan Kabupaten Bandung Barat dan wisatawan yang berkunjung ke destinasi wisata Sanghyang Kenit, di mana hasilnya dijelaskan sebagai berikut:

\section{1) Daya Tarik Wisata Alam di Sanghyang Kenit}

Kondisi alam Sanghyang Kenit masih terjaga, destinasi wisata ini menyuguhkan panorama alam yang indah dan sejumlah daya tarik wisata yang diuraikan dari aspek daya tarik wisata (keunikan, keaslian, kelangkaan, menumbuhkan semangat dan memberikan nilai bagi wisatawan), serta aspek komponen pariwisata (aksesibilitas, fasilitas, dan atraksi wisata) yang diuraikan sebagai berikut.

\section{a. Dari aspek keunikan}

Kawasan ini memiliki keunikan di mana kawasannya bersatu padu dengan cadas gamping yang terukir dengan ukuran besar dan tinggi. Pada bagian atas batu terdapat banyak tanaman liar yang tumbuh, serta di bagian bawah batu terdapat gemercik air yang berasal dari batu besar yang jatuh langsung ke dalam sungai. Di sepanjang sungai terdapat berbagai macam batuan dengan warna kuning keemasan yang khas.

Selain keunikan bebatuannya, air sungai juga sering berubah warna, terkadang biru jernih, kehijauan bahkan coklat, tergantung musim dan kondisi cuaca, namun air sungai sedikit berbusa. Menurut informan kunci (key informant), air pegunungan yang mengalir ke Sanghyang Kenit sangat jernih, namun karena air pegunungan bercampur dengan air dari PLTA Saguling maka kualitas airnya berubah menjadi sedikit berbusa.

b. Dari aspek keaslian

Kawasan ini terbentuk secara alami selama jutaan tahun terakhir dan memiliki keunikan serta keindahan alam yang alami, dimana tidak ada tanda-tanda perubahan atau 
kerusakan yang disebabkan oleh manusia. Hal ini dikarenakan sebelum dibangunnya PLTA Rajamandala, kawasan ini masih jarang dikunjungi orang, kecuali oleh masyarakat sekitar untuk memancing, atau memanfaatkannya sebagai akses ke lahan pertanian. Selain itu, di kawasan ini juga terdapat goa sepanjang 600 meter yang menghubungkan Sanghyang Kenit dengan Sanghyang Tikoro, sehingga melengkapi keindahan yang ada.

\section{c. Dari aspek kelangkaan}

Di kawasan ini terdapat goa yang bisa dijelajahi wisatawan. Di dalam goa terdapat stalaktit dan stalagmit yang terukir indah. Selain itu, di dalam goa terdapat beberapa kolam dengan air jernih yang bisa digunakan untuk berenang ataupun sekedar bermain air. Di kolam ini terdapat ikan baung yang sangat langka. Dengan perpaduan bentang alam berupa bebatuan dengan aliran air sungai yang tenang, jarang ditemui di destinasi wisata alam lainnya, sehingga dapat dikatakan Sanghyang Kenit memiliki kelangkaan yang tinggi.

\section{d. Menumbuhkan semangat dan memberikan nilai bagi wisatawan}

Mengingat Sanghyang Kenit merupakan sebuah kawasan yang unik dan indah, sehingga memberikan semangat bagi para wisatawan yang berkunjung. Bahkan menurut beberapa wisatawan, destinasi ini memberikan nilai-nilai tentang pentingnya keasrian alam dan juga sekaligus memberikan tantangan sebab disana ada tempat arung jeram yang jaraknya mencapai $7 \mathrm{~km}$. Pada aspek lain, Sanghyang Kenit memberikan manfaat positif bagi masyarakat sekitarnya. Banyak masyarakat yang ikut berpartisipasi, seperti menjadi pengelola destinasi, pemandu wisata, pedagang dan keterlibatan ibu-ibu PKK yang bertugas dalam menyiapkan konsumsi jika ada rombongan wisatawan.

\section{e. Dari aspek aksesibilitas}

Aksesibilitas merupakan hal penting yang dibutuhkan untuk mempermudah wisatawan menuju destinasi wisata, di mana akses untuk menuju lokasi Sanghyang Kenit sudah cukup bagus, jalan sudah beraspal dengan dua lajur dan dapat dilalui oleh kendaraan bus. Namun demikian belum adanya petunjuk arah yang dapat membantu wisatawan sampai ke lokasi. Menurut pihak Dinas Pariwisata Kabupaten Bandung Barat, mereka akan membantu membuat petunjuk arah bekerjasama dengan Dinas Perhubungan namun belum ditentukan secara spesifik pelaksanaannya.

Sedangkan akses jalan dari tempat parkir menuju lokasi berjarak 150 meter yang dapat ditempuh sekitar 5 menit dengan berjalan kaki (tracking). Namun jalan tersebut belum tertata rapi, pejalan masih menggunakan saluran air dengan ukuran yang tidak terlalu lebar, bahkan terkadang digunakan oleh kendaraan bermotor yang seharusnya parkir di tempat parkir yang telah disediakan. Hasil wawancara dengan pihak pengelola, mereka sudah merencanakan perbaikan akses tersebut namun belum ditentukan secara spesifik pelaksanaannya.

\section{f. Dari aspek fasilitas}

Fasilitas yang ada di kawasan ini antara lain area parkir yang luas, dan tempat istirahat yang cukup nyaman, di mana wisatawan bisa memasang hammock, menggelar tikar atau sekedar duduk di atas bebatuan untuk bersantai. Namun sayang tidak ada mushola untuk ibadah, toilet, ruang ganti, rambu keselamatan, dan terdapat sedikit tempat sampah. Di sisi lain, penataan lokasi atau sistem zonasi belum sepenuhnya diterapkan, dimana banyak pedagang membangun bangunan semi permanen yang terkesan kumuh. Sedangkan di aspek lain, lokasi ini bisa dikembangkan untuk kegiatan lainnya. 


\section{g. Dari aspek atraksi}

Wisatawan yang datang bisa menikmati keindahan alam dalam kondisi air sungai yang deras dan air surut. Saat air sedang surut, biasanya kolam digunakan wisatawan untuk berenang atau sekedar bermain air. Meski air yang mengalir cukup tenang, ada beberapa spot yang cukup dalam. Untuk itu wisatawan bisa menyewa ban karet atau pelampung yang telah disediakan pengelola. Saat air sedang deras, sungai ini bisa digunakan untuk arung jeram. Kegiatan lainnya, wisatawan bisa berfoto, menikmati suasana menggunakan hammock, atau menjelajahi stalaktit dan stalagmit dengan berjalan kaki menyusuri goa.

\section{2) Strategi Pengembangan Daya Tarik Wisata di Sanghyang Kenit}

Berdasarkan pengamatan lingkungan yang dilihat dari indikator daya tarik wisata yang meliputi; aspek keunikan, keaslian, kelangkaan, menumbuhkan semangat dan memberikan nilai bagi wisatawan serta indikator pengembangan pariwisata yang meliputi; aspek aksesibilitas, fasilitas dan atraksi wisata belum terlihat strategi yang sistematis. Maka dari itu, pembahasan strategi pengembangan daya tarik wisata alam di Sanghyang Kenit diuraikan sebagai berikut.

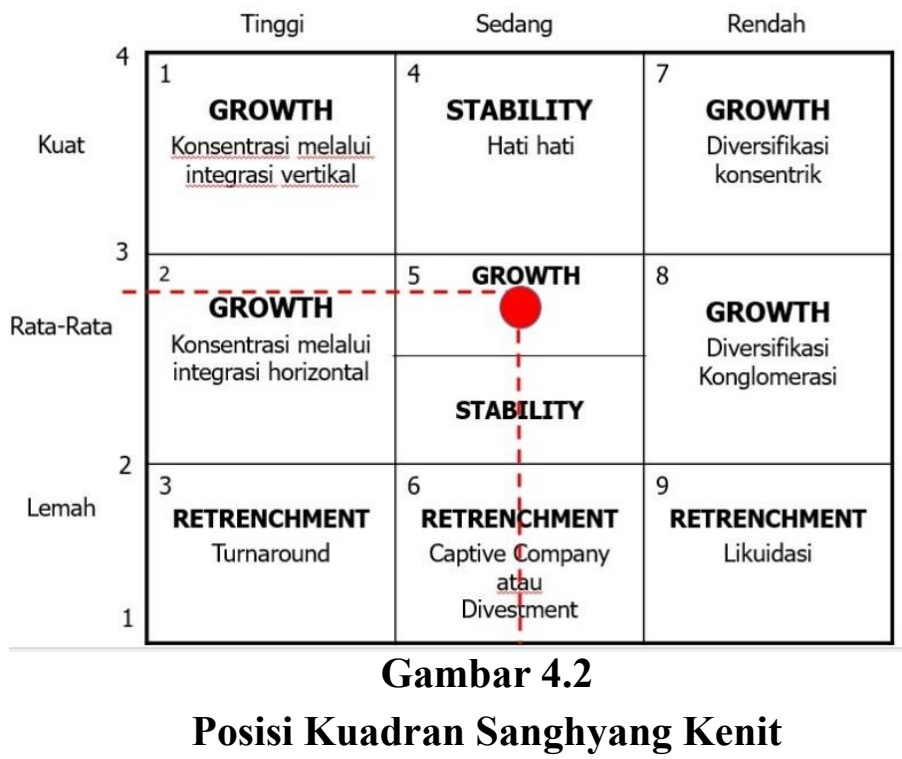

Untuk menghasilkan strategi pengembangan destinasi wisata di Sanghyang Kenit, maka peneliti menggunakan Matriks SWOT seperti terlihat dalam Tabel 4.1 di bawah ini.

Tabel 4.1

\section{Matriks SWOT}

\begin{tabular}{|l|l|l|}
\hline $\begin{array}{c}\text { FAKTOR-FAKTOR } \\
\text { INTERNAL (IFAS) }\end{array}$ & \multicolumn{1}{|c|}{ Kekuatan (S) } & Kelemahan (W) \\
& $\begin{array}{l}\text { 1. Panorama yang } \\
\text { terbentuk alami } \\
\begin{array}{l}\text { 2. Keunikan batuan cadas } \\
\text { gamping }\end{array}\end{array}$ & $\begin{array}{l}\text { 1. Petunjuk arah menuju } \\
\text { lokasi }\end{array}$ \\
$\begin{array}{l}\text { 2. Fasilitas toilet \& kamar } \\
\text { ganti }\end{array}$ \\
\hline
\end{tabular}




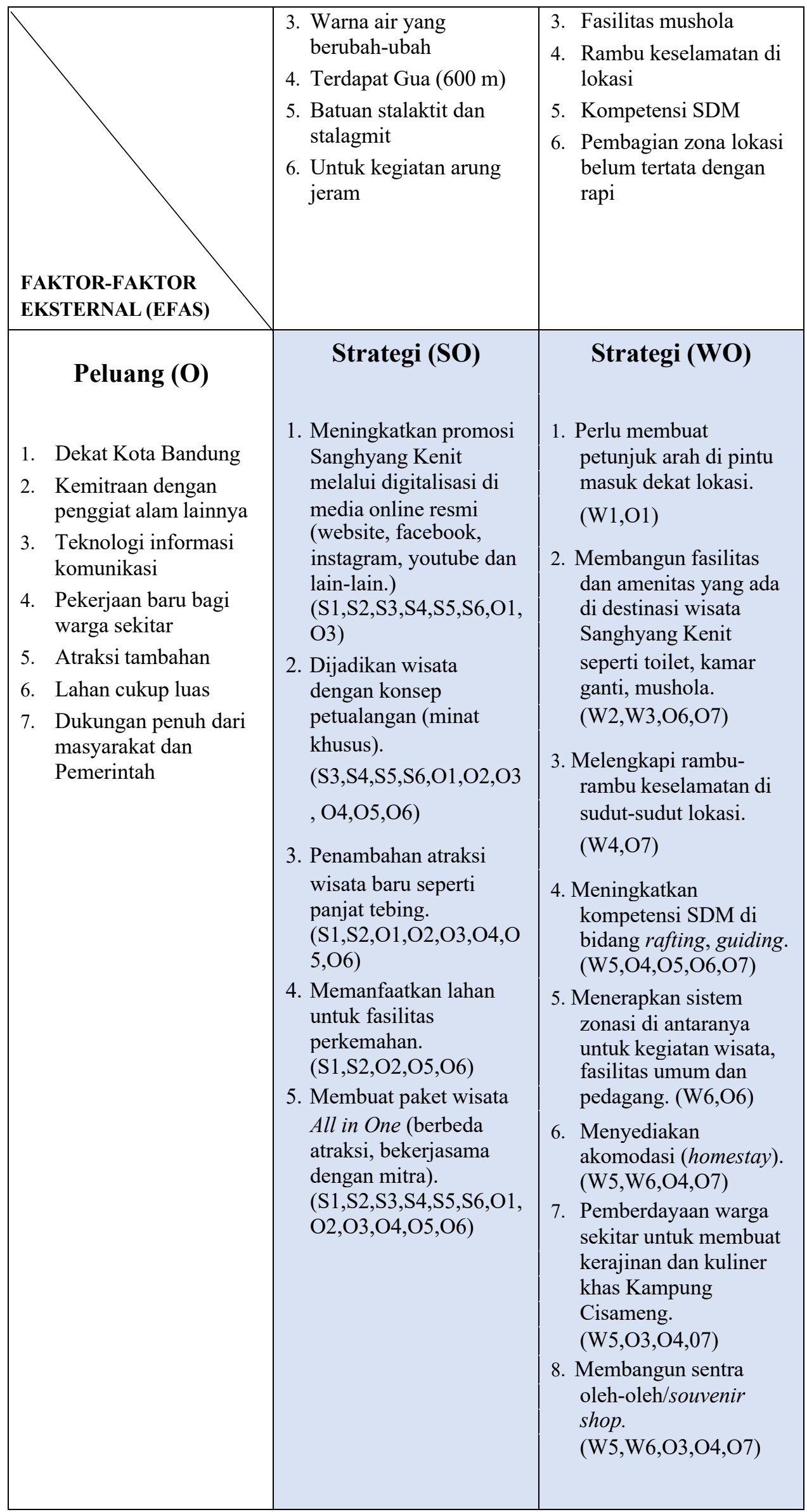




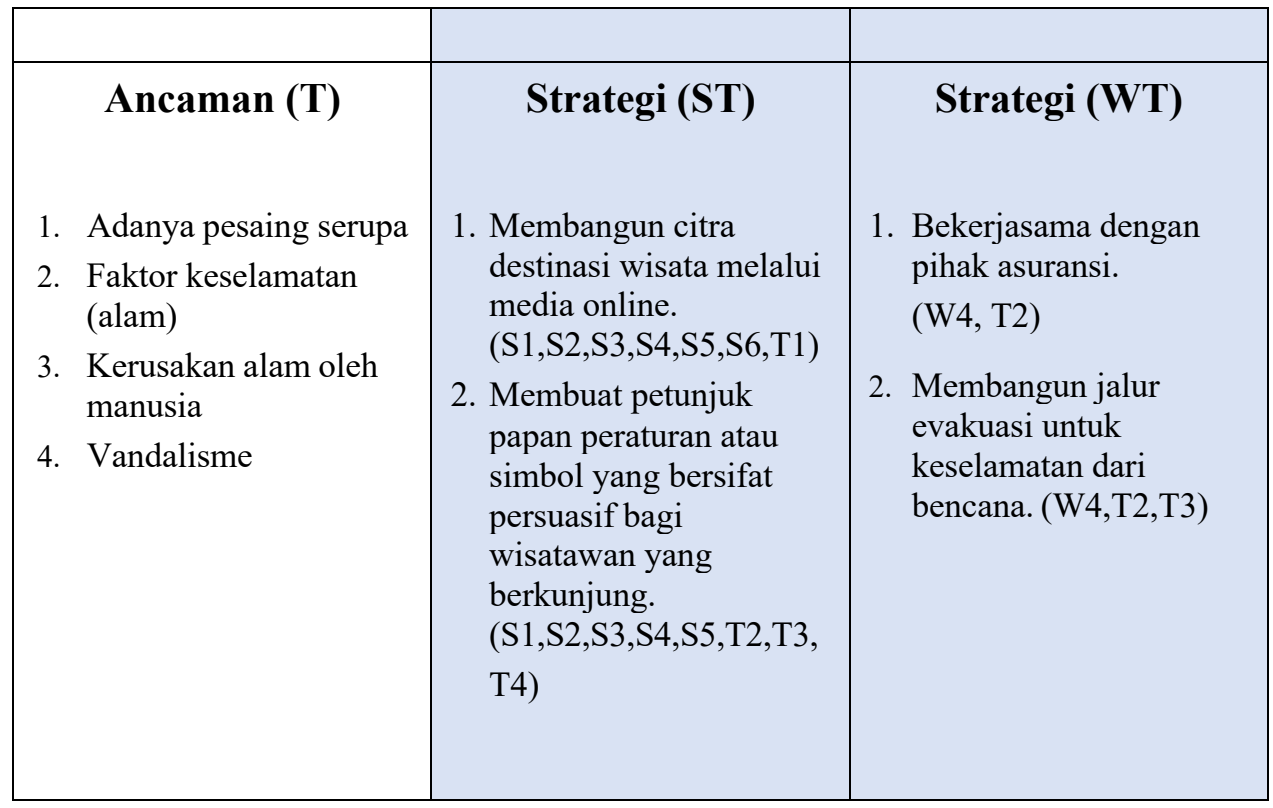

\section{Pembahasan}

\section{1) Daya Tarik Wisata Alam di Sanghyang Kenit}

Berdasarkan hasil penelitian menunjukkan bahwa, secara keseluruhan destinasi wisata Sanghyang Kenit sudah memenuhi aspek keunikan, keaslian, kelangkaan, menumbuhkan semangat dan memberikan nilai bagi wisatawan. Hal ini sejalan dengan teori Suryadana dan Oktavia (2015), di mana suatu daerah dikatakan memiliki daya tarik wisata bilamana memiliki sifat keunikan, keaslian, kelangkaan, menumbuhkan semangat dan memberikan nilai bagi wisatawan.

Sedangkan dari aspek komponen pengembangan pariwisata, jika dilihat dari tiga aspek (aksesibilitas, fasilitas dan atraksi wisata), akses jalan raya menuju lokasi sudah baik, namun akses tracking masih kurang layak dan perlu pembenahan. Begitu juga aspek fasilitas utama yang belum memadai, di mana belum ada toilet, mushola dan petunjuk arah. Sedangkan aspek atraksi wisata, memiliki keindahan alam yang sangat memukau. Namun mengingat masih ada aspek komponen pariwisata yang belum optimal, maka perlu adanya pengembangan yang terencana. Sebab, menurut Yoeti (dalam Edison., et.al. 2018), aksesibilitas, fasilitas, dan atraksi wisata merupakan faktor yang perlu diperhatikan dalam pengembangan pariwisata.

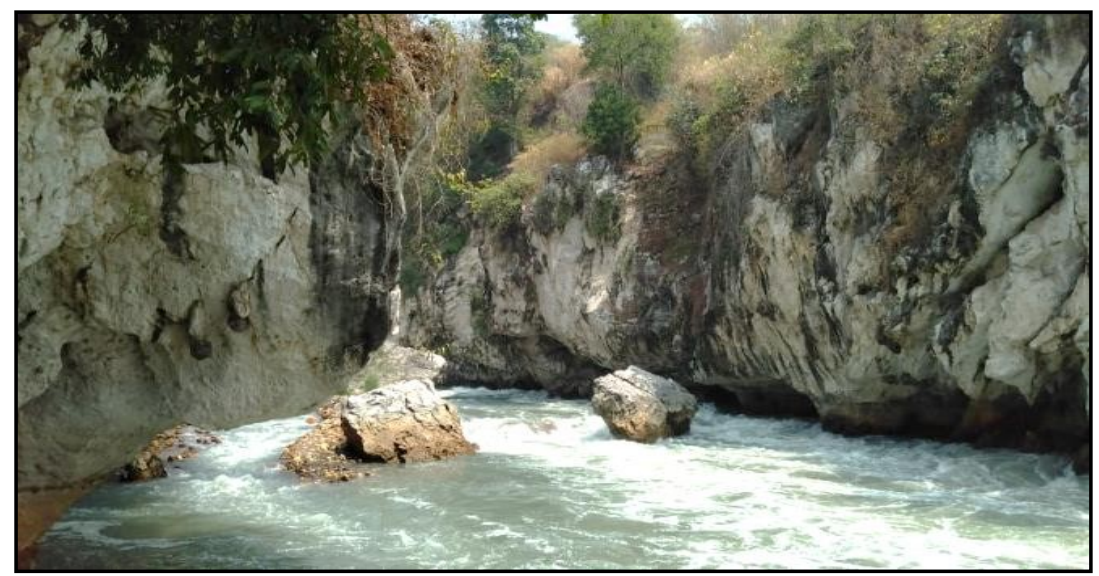




\section{Gambar 4.3}

Sanghyang Kenit (Kondisi Air Deras)

\section{2) Strategi Pengembangan Daya Tarik Wisata}

Strategi pengembangan daya Tarik wisata diambil berdasarkan strategi pencocokan menggunakan Matriks SWOT. Selanjutnya, strategi pengembangan disusun dalam rancangan rencana strategis (Tabel 4.2). Rancangan ini sejalan dengan teori Chandler (dalam Rangkuti, 2013) yaitu: "Strategi merupakan alat untuk mencapai tujuan perusahaan dalam kaitannya dengan tujuan jangka panjang, program tindak lanjut, serta prioritas alokasi sumber daya."

Tabel 4.2

Skala Prioritas Rencana Strategis

(Pengembangan Daya Tarik Wisata)

\begin{tabular}{|c|c|c|c|c|}
\hline \multirow{2}{*}{ No } & \multirow[t]{2}{*}{ Uraian } & \multicolumn{3}{|c|}{ Rencana Strategis } \\
\hline & & $\begin{array}{l}\text { Jangka } \\
\text { Pendek }\end{array}$ & $\begin{array}{c}\text { Jangka } \\
\text { Menengah }\end{array}$ & $\begin{array}{c}\text { Jangka } \\
\text { Panjang }\end{array}$ \\
\hline 1. & $\begin{array}{l}\text { Melakukan promosi melalui digitalisasi } \\
\text { di media online (website, facebook, } \\
\text { instagram, youtube dan lain-lain.) }\end{array}$ & $\checkmark$ & & \\
\hline 2. & $\begin{array}{l}\text { Menambah daya tarik wisata dengan } \\
\text { konsep petualangan (minat khusus) }\end{array}$ & & $\checkmark$ & \\
\hline 3. & Menambah atraksi wisata panjat tebing & & $\checkmark$ & \\
\hline 4. & $\begin{array}{l}\text { Menambah fasilitas untuk kegiatan } \\
\text { perkemahan }\end{array}$ & & $\checkmark$ & \\
\hline 5. & Membuat paket wisata & $\checkmark$ & & \\
\hline 6. & $\begin{array}{l}\text { Membuat petunjuk arah menuju lokasi } \\
\text { Sanghyang Kenit }\end{array}$ & $\checkmark$ & & \\
\hline 7. & Membangun fasilitas dan amenitas & $\checkmark$ & & \\
\hline 8. & $\begin{array}{l}\text { Membuat rambu-rambu keselamatan di } \\
\text { sudut-sudut lokasi }\end{array}$ & $\checkmark$ & & \\
\hline 9. & Meningkatkan kompetensi SDM & $\checkmark$ & & \\
\hline 10. & Melakukan sistem zonasi & $\checkmark$ & & \\
\hline 11. & Menyediakan akomodasi (homestay) & & & $\checkmark$ \\
\hline 12. & $\begin{array}{l}\text { Pemberdayaan warga sekitar untuk } \\
\text { membuat kerajinan dan kuliner khas } \\
\text { Kampung Cisameng. }\end{array}$ & $\checkmark$ & $\checkmark$ & \\
\hline 13. & $\begin{array}{l}\text { Membangun sentra oleh-oleh/souvenir } \\
\text { shop. }\end{array}$ & & $\checkmark$ & $\checkmark$ \\
\hline 14. & $\begin{array}{l}\text { Membangun citra destinasi melalui } \\
\text { media sosial }\end{array}$ & $\checkmark$ & $\checkmark$ & \\
\hline 15. & $\begin{array}{l}\text { Membuat papan peraturan atau simbol } \\
\text { yang bersifat persuasif untuk wisatawan }\end{array}$ & $\checkmark$ & & \\
\hline
\end{tabular}




\begin{tabular}{|c|l|c|c|c|}
\hline \multirow{2}{*}{$\begin{array}{c}\text { No } \\
\bullet\end{array}$} & \multicolumn{1}{|c|}{ Uraian } & \multicolumn{3}{|c|}{ Rencana Strategis } \\
\cline { 3 - 5 } & $\begin{array}{c}\text { Jangka } \\
\text { Pendek }\end{array}$ & $\begin{array}{c}\text { Jangka } \\
\text { Menengah }\end{array}$ & $\begin{array}{c}\text { Jangka } \\
\text { Panjang }\end{array}$ \\
\hline 16. & Bekerjasama dengan pihak asuransi & $\checkmark$ & $\checkmark$ & \\
\hline 17. & Membangun jalur evakuasi & $\checkmark$ & & \\
\hline
\end{tabular}

Rencana strategis jangka pendek, jangka menengah, dan jangka panjang dalam usaha pengembangan daya tarik wisata ini dapat diubah sesuai dengan kebutuhan.

\section{SIMPULAN}

Berdasarkan hasil penelitian dan pembahasan mengenai "Strategi Pengembangan Daya Tarik Wisata Alam di Sanghyang Kenit", maka dapat disimpulkan bahwa, secara keseluruhan destinasi wisata Sanghyang Kenit sudah memenuhi aspek keunikan, keaslian, kelangkaan, menumbuhkan semangat dan nilai bagi wisatawan. Sedangkan dari aspek komponen pariwisata, jika dilihat dari tiga aspek (aksesibilitas, fasilitas dan atraksi wisata), masih ada aspek komponen pariwisata yang belum optimal, seperti belum ada toilet, mushola, petunjuk arah, rambu-rambu keselamatan. Oleh karena itu, pengelola perlu melakukan langkah-langkah strategis yang terencana dan terukur, baik itu jangka pendek, menengah maupun panjang sehingga daya Tarik wisata yang adamakin lebih baik dan menjadi salah satu unggulan yang ada di Kabupaten Bandung Barat.

\section{DAFTAR PUSTAKA}

Edison, E., \& Reza, T.M. (2018). Potensi Alam Sungai Citarik Hilir Sebagai Wisata Minat Khusus Rafting Di Desa Pasirsuren Palabuhan Ratu. Tourism Scientific Journal, 4(1), 78-89.

Edison, E. (2020). Covid 19 dan Pariwisata: Pandemi Covid-19 dan Pentingnya Manajemen Krisis Kepariwisataan. Bandung: Stiepar Yapari Press

Edison, E., \& Wulandari, C. A. (2019). The effect of motivation and work discipline on employee performance In Cikole Jayagiri Resort. Tourism Scientific Journal, 5(1), 8396.

Kartika, T., Ruskana, R., \& Fauzi, M. I. (2018). Strategi Pengembangan Daya Tarik Dago Tea House Sebagai Alternatif Wisata Budaya di Jawa Barat. The Journal: Tourism and Hospitality Essentials Journal. 8(2). 121-138.

Khaerani, R., Pamungkas, P., \& Aeni, S. N. (2017). Pengembangan Daya Tarik Wisata Daarus Sunnah Menjadi Wisata Halal. Tourism Scientific Journal, 3(1), 92-113.

Lesmana, A.C., \& Astuti, N. A. (2018). Perayaan Pesta Nelayan Sebagai Daya Tarik Wisata Dalam Mempromosikan Pariwisata di Palabuhanratu Sukabumi. The Journal: Tourism and Hospitality Essentials Journal. 8(2). 89-98.

Moleong, L. J., (2011). Metode Penelitian Kualitatif. Bandung: PT. Remaja Rosdakarya Offset.

Rangkuti, F. (2013). ANALISIS SWOT: Teknik Membedah Kasus Bisnis. PT. Gramedia Pustaka Utama: Jakarta.

Sugiyono. (2010). Metode Penelitian Kuantitatif, Kualitatif dan R\&D. Bandung: Alfabeta 
Sugiyono. (2016). Metode Penelitian Pendidikan Pendekatan Kuantitatif, Kualitatif, dan R\&D. Bandung: Alfabeta

Sunaryo, B. (2013). Kebijakan Pembangunan Destinasi Pariwisata Konsep dan Aplikasinya di Indonesia. Yogyakarta: Penerbit Gava Media.

Suryadana, M. L., \& Oktavia, V. (2015). Pengantar Pemasaran Pariwisata. Bandung: Alfabeta Zebua, M. (2016). Inspirasi Pengembangan Pariwisata Daerah. Yogyakarta: Deepublish. 